\title{
PENGARUH PERENDAMAN JENIS BUAH TERHADAP PENURUNAN KADAR KADMIUM (Cd) PADA UDANG VANNAME Litopenaeusvannamei) TAMBAK INTENSIF DEKAT DAN JAUH MANGROVE
}

\author{
Bella Anggraini ${ }^{1 *}$, Hening Widowati ${ }^{2}$, Widya Sartika Sulistiani ${ }^{3}$ \\ ${ }^{1,2}$ Universitas Muhammadiyah Metro \\ E-mail: ${ }^{1 *} 0727$ bellanggra@gmail.com, ${ }^{2}$ hwummetro@gmail.com, \\ ${ }^{3}$ widya.sulistiani@gmail.com
}

\begin{abstract}
Abstrak: Udang vanname (Litopenaeus vannamei) memiliki sifat filter feeder yang dapat menyaring semua makanan yang terdapat pada sedimen. Logam $\mathrm{Cd}$ adalah jenis logam yang akan mengendap di sedimen. $\mathrm{Cd}$ dapat terakumulasi pada tubuh udang dan membahayakan kesehatan manusia jika dikonsumsi. Tujuan penelitian adalah 1) untuk mengetahui pengaruh perendaman buah terhadap penurunan kadar $\mathrm{Cd}, 2$ ) untuk mengetahui Jenis buah yang lebih tepat untuk menurunkan kadar Cd pada Udang Vanname di tambak intensif jauh dan dekat mangrove dan 3) membuat poster sebagai media belajar siswa kelas X SMA materi Pencemaran Lingkungan. Penelitian dilakukan dengan metode RAKL (Rancangan Acak Kelompok Lengkap) dan dianalisis dengan uji anava satu arah untuk mengetahui pengaruh buah terhadap penurunan kadar Cd. Penelitian dilaksanakan pada bulan April 2020 di Pasir Sakti Lampung Timur dan dianalisis di Laboratorium Analitik Kimia Universitas Muhammadiyah Malang. Hasil penelitian menunjukkan bahwa perendaman daging udang vanname dengan menggunakan jenis buah memberikan pengaruh penurunan kadar $\mathrm{Cd}$ pada daging udang. Jenis buah yang memberikan pengaruh penurunan paling baik adalah jeruk nipis yang mampu menurunkan $\mathrm{Cd}$ menjadi sebesar $270,87 \mathrm{ppb}$ atau turun sebesar $46,28 \%$ pada udang tambak intensif dekat mangrove, dan mampu menurunkan Cd menjadi sebesar 521,4 ppb atau turun sebesar 44,62\% untuk tambak intensif jauh mangrove. Penelitian ini menghasilkan sumber belajar poster yang layak digunakan dalam pembelajaran biologi SMA kelas X materi Pencemaran Lingkungan.
\end{abstract}

Kata Kunci : Penurunan kadar Cd; poster pembelajaran; udang vanname (Litopenaeus vannamei);

\begin{abstract}
Abstrack: Vanname shrimp (Litopenaeus vannamei) has filter feeder properties that can filter all the food contained in the sediment. Cd is a type of metal that will settle in the sediment. Cd can accumulate in the shrimp body and endanger human health if consumed. The objectives of study were 1) to determine the effect of immersion of fruits on the reduction of Cd levels, 2) to determine which types of fruits were more appropriate to reduce Cd levels in Vanname Shrimp in remote and intensive ponds. near mangroves and 3) to make posters as learning media for class X high school on environmental pollution. The research was conducted using the CRBD method (completely randomized block design) and analyzed with a one-way anova test to determine the effect of fruits on the reduction of Cd levels. The research was conducted in April 2020 in Pasir Sakti, East Lampung and analyzed at the Chemical Analytical Laboratory of the Muhammadiyah University of Malang. The results showed that soaking vanname shrimp using fruits had the effect of reducing Cd levels in shrimp meat. The type of fruits that gave the best reduction effect was Citrus aurantiifolia which was able to reduce the Cd to $270.87 \mathrm{ppb}$ or decreased by $46.28 \%$ for intensive pond shrimp near mangroves, and able to reduce the Cdto 521.4 ppb or decreased by $44.62 \%$ for intensive mangroves distant pond. This research produces learning resources in the form of posters that are suitable for use in class $X$ high school biology learning environmental pollution material.
\end{abstract}

Keywords: decreased levels of Cd.; learning posters; vanname shrimp (Litopenaeus vannamei)

\section{How to Cite}

Anggraini, Bella, Hening Widowati, Widya Sartika Sulistiani. 2021. Pengaruh Perendaman Jenis Buah terhadap Penurunan Kadar Kadmium (Cd) pada Udang Vanname (Litopenaeus vannamei) Tambak Intensif Dekat dan Jauh Mangrove. Biolova 2(2). 151-163. 
Udang vanname (Litopenaeus vannamei) merupakan udang putih yang banyak dipilih sebagai udang budidaya karena memiliki nafsu makan yang tinggi dan tidak mudah terserang penyakit. Tingkat konsumsi udang ini terbilang tinggi karena minat masyarakat, minat masyarakat terhadap udang vanname didukung dengan kandungan protein, gizi dan harga yang terjangkau, selain tahan terhadap kondisi lingkungan dan penyakit, tubuhnya dapat menyerap timbal dan logam berat sehingga ia dapat dijadikan sebagai bioindikator pencemaran air (Saadah dan Milah, 2019).

Udang vanname (Litopenaeus vannamei) yang terdapat di Pasir Sakti dibudidayakan dengan 3 jenis tambak yaitu dengan tambak tradisonal, intensif dan semi intensif. Budidaya yang banyak dipilih olehpembudidaya adalah budidaya dengan tambak intensif, hal ini dikarenakan tambak intensif sudah termodifikasi baik dalam bentuk pakan ataupun pembuatan tambaknya, sehingga menghasilkan udang lebih banyak dan dengan ukuran yang lebih besar. Pembuatan tambak udang intensif diawali dengan proses penaburan pupuk urea pada tambak, hal ini bertujuan untuk menjadikan tanah semakin subur dan menghasilkan banyak mikroorganisme yang bisa dijadikan pakan alami udang vanname. Namun, disamping itu timbul masalah yang perlu diperhatikan. "Pupuk urea (TPS) mengandung fosfat $40-46 \%$ ), NPK mengandung fosfat $15 \%$, dan Kandungan $\mathrm{Cd}$ dalam pupuk fosfat rata-rata $\quad 138 \quad \mathrm{mg}$ $\mathrm{Cd} / \mathrm{kg}$ '(Kusumaningrum, dkk., 2012:100). Sehingga dalam proses pembuatan tambak sudah berpotensi tercemar logam $\mathrm{Cd}$.
Tambak intensif di Pasir Sakti dibuat dengan dua tipe tambak, yaitu intensif jauh dari mangrove dan intensif dekat mangrove. Intensif jauh mangrove dekat dengan pemukiman warga dan jalan raya. Hal ini menimbulkan masalah pencemaran pada perairan tambak. Pencemaran pada lingkungan perairan dan tanah dapat disebabkan karena pembuangan limbah industri secara sembarangan, penggunaan pestisida, asap kendaraan, kegiatan rumah tangga yang menghasilkan asap pembakaran sampah dan limbah air yang dibuang diperairan memicu terjadinya pencemaran logam berat (Nur, 2013). Namun disamping hal tersebut tambak intensif dekat mangrove juga berpotensi tercemar kadmium (Cd), mengingat mangrove sendiri merupakan tanaman yang berfungsi sebagai biofilter dan bioremidiasi.

Menurut Gunarto yang dikutip Khairuddin (2018: 71) "Mangrove adalah Tumbuhan yang memiliki kemampuan biofilter, yang artinya dapat menyaring, mengikat, dan memerangkap polusi di alam bebas berupa kelebihan sedimen dan juga logam berat".

Udang vanname yang dibudidayakan dikedua tambak tersebut memiliki kemungkinan besar tercemar logam kadmium (Cd), hal ini dilihat dari keadaan lingkungan tambak dan pola hidup udang itu sendiri. Jenis hewan filum crustacea seperti "Kepiting, umang-umang dan udang merupakan jenis hewan karnivora, dan penyaring makanan pada endapan sedimen (filter feeder deposit feeder)" (Irawan dan Yandri, 2015: 47). Udang memiliki kemampuan menyaring semua makanan yang terdapat pada sedimen, sedangkan logam jenis kadmium $(\mathrm{Cd})$ adalah jenis logam yang berada pada 
sedimen. Sifat filter feeder ini menyebabkan logam berat masuk dan terakumulasi pada tubuh udang dan akan terakumulasi pada tubuh manusia ketika udang dikonsumsi.

Kadmium (Cd) jika dikonsumsi melampaui ambang batas normal maka akan berpengaruh pada kesehatan masyarakat. Menurut BPOM Indonesia (2018:3) "batas maksimum $\mathrm{Cd}$ pada daging ikan dan produk perikanan seperti crustacea adalah $0,10 \mathrm{mg} / \mathrm{kg}$ ". Apabila terlalu sering mengkonsumsi makanan dengan kandungan kadmium (Cd) baik dalam jumlah sedikit atau banyak akan tetap berpengaruh pada kesehatan. Kadmium (Cd) masuk ketubuh manusia melalui makanan akan mengendap diginjal dan menggangu fungsi ginjal serta dapat menyerang dan merusak hati, testis, jantung, otak dan sistem peredaran darah manusia (Indirawati, 2017). Mengingat bahayanya mengkonsumsi udang yang terkontaminasi Cd maka dari itu cara pengolahan udang harus diperhatikan, terutama ketika udang masih dalam keadaan segar.

Upaya untuk menurunkan kadar Cd pada daging udang dapat dilakukan dengan memanfaatkan beberapa jenis buah yang mengandung asam sitrat sebagai perendam udang.

Menurut Ondu, dkk., (2019:3) menyatakan bahwa Asam sitrat $\left(\mathrm{C}_{6} \mathrm{H}_{8} \mathrm{O}_{7}\right)$ memiliki kemampuan untuk mengikat logam berat yang terdapat pada biota air. Kandungan asam sitrat dapat ditemukan pada buah Citrus aurantifolia dan Averrhoa bilimbi, sehingga buah tersebut dapat dijadikan sulosi untuk menurunkan kadar Logam berat yang terakumulasi di tubuh biota air.
Jenis buah yang mengandung asam sitrat dapat digunakan sebagai bahan perendaman udang untuk menurunkan kadar $\mathrm{Cd}$ yang terakumulasi di dalamnya. Buah dengan kandungan asam sitrat banyak terdapat di lingkungan masyarakat, tidak hanya jeruk nipis dan belimbing wuluh namun juga seperti markisa dan tomat (Surest, dkk, 2013). Penelitian yang dilakukan hanya menetapkan pengunaan 4 jenis buah yang mengandung asam sitrat sebagai bahan perendaman udang, yaitu buah jeruk nipis, jeruk lemon, nanas dan juga asam jawa.

Nurmalasari dan Zaenab (2017: 173) dalam penelitiannya menyimpulkan bahwa "air perasan jeruk nipis efektif menurunkan kadar logam $\mathrm{Pb}$ pada daging kerang Marcia hiantina", sehingga hal ini dapat dijadikan acuan bahwa air perasan jeruk nipis juga dapat menurunkan kadar Cd pada daging udang. Selain jeruk nipis, nanas dan asam jawa juga memiliki potensi yang sama dalam hal penurunan logam berat. Hal ini dikuatkan dari penelitian yang dilakukan oleh Sipa dkk tahun 2016. "Kadar $\mathrm{Pb} 0,8 \mathrm{mg} / \mathrm{kg}$ pada daging ikan teri turun menjadi $0,7872 \mathrm{mg} / \mathrm{kg}$ (asam jawa 5\%); 0,7884 mg/kg (filtrat nanas $100 \%) ; \quad 0,7892 \mathrm{mg} / \mathrm{kg}$ (belimbing wuluh 100\%) dan 0,7916 $\mathrm{mg} / \mathrm{kg}$ (jeruk nipis 25\%)" (Sipa, dkk., 2016:85). Penelitian ini dapat dijadikan penguat bahwa buah jeruk nipis, lemon, nanas dan asam jawa yang digunakan juga memiliki efektifitas yang baik dalam penurunan kadar $\mathrm{Cd}$ pada daging udang vanname.

Pemanfaatan jenis buah alami untuk penurunan kadar kadmium (Cd) pada daging udang Vanname dijadikan sebagai sumber belajar bagi peserta didik dalam memahami 
materi Pencemaran Lingkungan, sumber belajar ini berupa poster. Poster adalah media grafis penyampai pesan yang baik, berfungsi menyalurkan pesan, menarik perhatian dengan sajian yang didominasi gambar dan ide pokok yang mudah diingat (Megawati, 2017). Sehingga poster dapat dijadikan sebagai media pembelajaran yang mudah untuk dipahami oleh peserta didik.

Penelitian bertujuan untuk mengetahui apakah terdapat pengaruhperendaman Jenis Buah terhadap Penurunan Kadar kadmium (Cd) dan jenis buah manakah yang memberikan penurunan $\mathrm{Cd}$ paling baik pada Udang Vanname (Litopenaeus vannamei) ditambak Intensif Dekat dan Jauh Mangrove Pasir Sakti Lampung Timur.

\section{METODE PENELITIAN}

Metode penelitian yang digunakan adalah metode rancangan acak kelompok lengkap (RAKL). Teknik pengambilan sampel yang digunakan adalah Simple random sampling, teknik ini adalah teknik pengambilang sampel secara acak sehingga setiap satuan sampling yang ada dalam populasitambak mempunyai peluang yang sama untuk dipilih kedalam sampel.Sampel udang yang digunakan didapatkan dari dua tambak intensif, yaitu intensif jauh dan dekat mangrove. sampel diambil sebanyak $1 \mathrm{~kg}$ pada masing-masing tambak.

Penelitian ini menggunakan Analisis Varians (ANAVA) satu arah. Uji ANAVA satu arah ini harus melewati uji Normalitas, dan uji Homogenitas. Uji analisis varians (ANAVA) satu arah dapat dilakukan jika data berdistribusi normal dan homogen dengan menggunakan uji normalitas (Liliefors) dan homogenitas (Barlett),uji Hipotesis, Kemudian jika terdapat pengaruh yang signifikan maka dilanjutkan uji Beda Nyata (BNJ) yaitu untuk mengetahui jenis buah yang memberikan pengaruh pernurunan paling baik. Mencari nilai BNJ dapat dilihat dibawah ini:

$$
\mathrm{BNJ}=\mathrm{Q} \times \mathrm{S}_{\overline{\mathrm{y}}}
$$

Keterangan:

$\mathrm{S}_{\overline{\mathrm{y}}}=$ nilai simpangan baku

$\mathrm{Q}=$ didapat dari daftar tabel $\mathrm{Q}$

\section{HASIL PENELITIAN DAN PEMBAHASAN}

\section{Hasil Penelitian}

Data hasil analisis kadar logam kadmium $(\mathrm{Cd})$ diperoleh dari setiap perlakuan dan ulangan yang dilakukan pada udang vanname dari kedua tambak.

Data yang dihasilkan memiliki variasi kadar kadmium yang berbeda, data hasil analisis tersebut dapat dilihat pada tabel 1 dan 2 berikut ini: 
Tabel 1. Kadar Logam Kadmium (Cd) Daging Udang Vanname Tambak Intensif Dekat Mangrove $(\mu \mathrm{g} / \mathrm{kg})$

\begin{tabular}{|c|c|c|c|c|c|}
\hline \multirow{2}{*}{ Ulangan } & \multicolumn{5}{|c|}{ Kadar Logam Cd pada Perlakuan } \\
\hline & Kontrol & Asam Jawa & Jeruk Nipis & $\begin{array}{l}\text { Jeruk } \\
\text { Lemon }\end{array}$ & Nanas \\
\hline U1 & 490,90 & 322,97 & 268,4 & 335,02 & 278,06 \\
\hline $\mathrm{U} 2$ & 495,4 & 323,29 & 268,56 & 334,82 & 282,25 \\
\hline $\mathrm{U3}$ & 515,87 & 329,36 & 271,98 & 356,59 & 285,93 \\
\hline $\mathrm{U} 4$ & 514,85 & 328,57 & 274,54 & 359,86 & 284,32 \\
\hline $\begin{array}{l}\text { Jumlah Rata- } \\
\text { rata }\end{array}$ & 504,26 & 326,05 & 270,87 & 346,57 & 282,64 \\
\hline
\end{tabular}

Tabel 2. Kadar Logam Kadmium (Cd) Daging Udang Vanname Tambak Intensif Jauh Mangrove ( $\mu \mathrm{g} / \mathrm{kg})$

\begin{tabular}{lllllc}
\hline \multirow{2}{*}{ Ulangan } & \multicolumn{5}{c}{ Kadar Logam Cd pada Perlakuan } \\
\cline { 2 - 5 } & Kontrol & Asam Jawa & Jeruk Nipis & Jeruk \\
Lemon & Nanas \\
\hline U1 & 961,69 & 616,73 & 524,51 & 665,35 & 547,64 \\
\hline U2 & 959,12 & 621,85 & 528,11 & 660,12 & 552,09 \\
\hline U3 & 925,05 & 616,49 & 520,09 & 646,06 & 551,65 \\
\hline U4 & 919,82 & 607,21 & 512,89 & 643,34 & 546,98 \\
\hline Jumlah Rata- & 941,42 & & & & 549,59 \\
rata & & & & & \\
\end{tabular}

Berdasarkan data Tabel 1 dan 2 maka dapatdideskripsikan bahwa kadar kadmium (Cd) pada daging udang vanname di tambak intensif dekat dan jauh mangrove memiliki nilai rata-rata kadar kadmium $(\mathrm{Cd})$ yang berbeda pada masing- masing perlakuan. Perlakuan pertama berupa kontrol pada tambak intensif dekat mangrove memiliki kadar kadmium rata-rata 504,26 ppb dan jauh mangrove sebesar 941,42 ppb. 
Perlakuan kedua dengan perendaman esktrak asam jawa pada udang vanname tambak intensif dekat mangrove memiliki rata-rata kadar kadmium yang lebih kecil dari kontrol yaitu sebesar 326,05 ppb dan intensif jauh mangrove 615,57 ppb. Perendaman dengan jeruk nipis sebesar 270,87 ppb dan 521,4 ppb, jeruk lemon menjadi rata-rata sebesar 346,57 dan $653,72 \mathrm{ppb}$, perlakuan ke lima perendaman dengan sari buah nanas menghasilkan rata-rata kadar kadmium yang juga mengalami penurunan dibandingkan kontrol yaitu sebesar 282,64 ppb pada daging udang tambak intensif dekat mangrove dan 549,59 ppb pada tambak intensif jauh mangrove.

\section{PEMBAHASAN}

\section{Pengaruh Perendaman Jenis Buah terhadap Penurunan Kadar Kadmium (Cd) pada Udang Vanname (Litopenaeus vannamei) di Tambak Intensif Dekat dan Jauh Mangrove.}

Berdasarkan hasil analisis tersebut dapat dibuktikan bahwa udang vanname (Litopenaeus vannamei) yang terdapat pada tambak intensif jauh dan dekat mangove mengandung logam berat $\mathrm{Cd}$ dengan masing-masing kontrol sebesar 504,26 ppb dan 941,42 ppb.

Menurut BPOM Indonesia (2018: 3) "batas maksimum Cd pada daging ikan dan produk perikanan seperti crustacea adalah $0,10 \mathrm{mg} / \mathrm{kg}$ ". Berdasarkan pernyataan yang ditetapkan oleh BPOM Indonesia diketahui bahwa $\mathrm{Cd}$ yang terkandung pada udang vanname ini masih tidak melebihi ambang batas konsumsi, karena941,42 ppb setara dengan
0,00000000941 $\mathrm{mg} / \mathrm{kg}$ dan 504,26 ppb atau setara dengan $0,00000000504 \mathrm{mg} / \mathrm{kg}$, namun akan mengganggu kesehatan jika terus dikonsumsi.

Berdasarkan hasil uji hipotesisdidapatkan data pada tambak intensif dekat dan jauh mangrove nilai $F_{1}$ hitung $>F_{1}$ tabel. (dekat mengrove $F_{1 h i t u n g} 1430,84>F_{1 \text { tabel }} 2,87$ dan jauh mangrove $F_{1 \text { tabel }}\left(F_{1 \text { hitung }} 2033,6>F_{1}\right.$ tabel 2,87) maka dikatakan bahwa terdapat pengaruh perendaman jenis buah terhadap penurunan kadar kadmium (Cd) pada daging udang vannamei di tambak intensif jauh dan dekat mangrove yang dibuktikan dengan $F_{\text {hitung }}>F_{\text {tabel. }}$

Nilai penurunan kadar kadmium (Cd) setelah perendaman dengan jenis buah menunjukkan kisaran kadar yang berbeda, adapun nilai penurunan kadar kadmium $(\mathrm{Cd})$ pada masing-masing perlakuan ditunjukkan oleh Tabel 1 dan 2 di atas. Perendaman dengan menggunakan asam jawa turun menjadi 326,05 ppb atau turun sebanyak $35,34 \%$ dari rata-rata ulangan pada udang tambak intensif dekat mengrove. Udang tambak intensif jauh mangrove turun menjadi $615,57 \mathrm{ppb}$ atau sebanyak $34,61 \%$.

Asam jawa mampu menurunkan kadar Cd pada udang karena memiliki kandungan asam sitrat. Asam sitrat mempunyai affinitas yang tinggi terhadap kation logam dan merupakan asam yang dapat membentuk gugus ester, asam sitrat yang terkandung dalam asam jawa ini menjadi bahan utama yang dapat menurunkan kadar logam. hal ini terjadi karena asam sitrat memiliki gugus fungsional yang dapat 
mengikat logam berat (Maulana, dkk :2018)

Perlakuan ketiga perendaman dengan jeruk nipis turun menjadi 270,87 ppbatau turun sebanyak $46,28 \%$ dari tambak intensif dekat mangrove dan menjadi 521,4 ppb atau turun sebanyak $44,61 \%$ pada udang tambak intensif jauh mangrove.Perlakuankeempat dengan menggunakan jeruk lemonturun menjadi 346,57 ppb atau sebanyak $31,27 \%$ dari rata-rata ulangan pada tambak dekat mengrove dan 653,72 ppb atau turun sebanyak $30,56 \%$ pada tambak jauh mangrove.

Perlakuan kelima adalah perendaman dengan menggunakan sari nanas. Rohmana, dkk (2015:61) menyatakan bahwa " nanas (Ananas comosus) banyak mengandung senyawa asam sitrat" oleh sebab itu nanas juga memiliki potensi besar dalam menurunkan kadar $\mathrm{Cd}$ pada daging udang. Daging udang tambak intensif dekat mangrove yang direndam dengan nanas turun menjadi 282, 64 ppb atau sebanyak 43,95\% dari nilai rata-rata dan jauh mangrove sebesar 549,59 ppb atau sebanyak $41,62 \%$ dari nilai rata-rata setiap ulangan.

Pengaruh penurunan kadar $\mathrm{Cd}$ pada setiap perlakuan tidak menunjukkan adanya perbedaan yang jauh, artinya lokasi tambak dalam penelitian ini tidak mempengaruhi penurunan $\mathrm{Cd}$ melainkan hanya mempengaruhi tinggi atau rendahnya kadar pencemaran saja, hal ini dikarenakan banyak aktifitas yang menjadi sumber pencemaran $\mathrm{Cd}$ yang dilakukan di tambak intensif jauh mangrove, sedangkan tambak dekat mangrove aktifitas yang menjadi sumber pencemaran rendah dan pencemaran yang ada di lingkungan tambak langsung diserap oleh tanaman mangrove itu sendiri.

Penurunan kadar $\mathrm{Cd}$ yang terdapat di daging udang disebabkan oleh adanya kandungan asam sitrat pada jenis-jenis buah yang digunakan. Yusbarina dan Marlianis (2013: 2) menyatakan bahwa Asam sitrat merupakan jenis asam organik lemah. Asam sitrat termasuk zat pengikat logam yang termasuk zat penstabil dalam pengolahan bahan makanan. Asam sitrat mengikat logam dalam bentuk senyawa kompleks sehingga dapat mengalahkan sifat dan pengaruh jelek logam yang terdapat pada bahan makanan.

Asam sitrat adalah asam sederhana. Penggunaan bahan asam sederhana ini dipilih agar daging udang yang direndam dengan jenis asam alami ini tetap dalam keadaan gizi yang baik, baik kalsium ataupun proteinnya. Bahan asam alami mudah ditemukan oleh masyarakat dengan harga terjangkau, sehingga tetap baik dikonsumsi, mudah didapat dan logam berat pun dapat mengalami penurunan.

Asam sitrat yang terkandung dalam jenis buah yang digunakan memiliki 3 gugus karboksil yang dapat bereaksi dengan ion logam dan menjadi penyebab turunnya $\mathrm{Cd}$ pada daging udang. Priyadi dkk (2014: 412) menyatakan bahwa Gugus fungsional karboksil - $\mathrm{COOH}$ asam sitrat mengalami deprotonasi menghasilkan speudo penukar ion yang bersifat aktif $-\mathrm{COO}^{-}$dan ion $\mathrm{H}^{+}$ sebagai donor proton yang membentuk logam netral, sehingga terbentuk $\mathrm{Cd}^{2+}$ atau $\mathrm{Pb}^{2+}$, proses khelasi terjadi yaitu ion logam bebas 
diikat ion $-\mathrm{COO}^{-}$membentuk komplek ligan.

Logam seperti $\mathrm{Cd}$ dan $\mathrm{Pb}$ terikat dalam protein daging organisme sehingga membentuk senyawa metaloenzim dengan adanya asam sitrat yang memiliki 4 eletron bebas yang diberikan pada ion logam, maka $\mathrm{Pb}$ ataupun $\mathrm{Cd}$ akan terlepas dan berikatan dengan ion $\mathrm{OH}-$ dan $\mathrm{COOH}$ - yang ada pada asam sitrat dan membentuk senyawa $\mathrm{Pb}$ sitrat atau pun kadmium sitrat $\left(\mathrm{C}_{12} \mathrm{H}_{10} \mathrm{CD}_{3} \mathrm{O}_{14}\right)$. Logam yang terakumulasi di dalam tubuh suatu organisme akan terikat dengan protein yang terdapat dalam tubuh organisme tersebut, maka ketika udang vanname mengandung $\mathrm{Cd}$ maka $\mathrm{Cd}$ ini sudah dipastikan akan terikat dengan protein yang ada pada daging udang, sehingga ketika terdapat zat yang mengikat logam maka protein pada udang sedikit banyak akan berkurang (Izza, 2014).

Asam sitrat memiliki 4 eletron bebas dan 3 gugus karboksil berupa $\mathrm{COOH}$, sehingga asam sitrat dapat mengikat Cd karena logam berat $\mathrm{Cd}$ dapat terikat oleh atom yang memiliki ion bebas seperti asam sitrat. Gugus karboksil asam sitrat tersebut dapat melepas proton dalam larutan, proton yang terlepas ini berupa ion $\mathrm{H}+$, ion $\mathrm{H}^{+}$sebagai donor proton ini yang membentuk logam netral, sehingga $\mathrm{Cd}$ dalam daging udang terbentuk menjadi $\mathrm{Cd}^{2+}$ (Ilyasa, 2016). Ketika daging udang yang mengandung $\mathrm{Cd}$ direndam dengan jenis asam alami yang mengandung asam sitrat maka ion yang terlepas dari asam sitrat tersebut akan bereaksi dengan ion logam Cd. Ion sitrat ini akan mengikat ion logam $\mathrm{Cd}$ dan terjadi yang namanya proses khelasi. Reaksi gugus karboksil dengan $\mathrm{Cd}$ dapat dilihat pada gambar 1 .

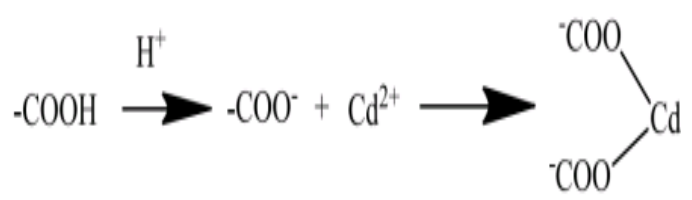

Gambar 1. Reaksi Gugus Karboksil dengan $\mathrm{Cd}$.

(Sumber: Ilyasa, dkk., 2016: 214)

Khelasi ini terjadi karena adanya zat penghelat, zat tersebut merupakan asam sitrat yang berasal dari jenis asam alami yang digunakan yaitu jeruk nipis, lemon, asam jawa, dan juga nanas. Proses khelasi menyebabkan logam bebas diikat oleh ion -COO- dan membentuk ion komplek. Maka terjadilah perubahan $\mathrm{Cd}$ menjadi $\mathrm{Cd}$ sitrat $\left(\mathrm{C}_{12} \mathrm{H}_{10} \mathrm{Cd}_{3} \mathrm{O}_{14}\right)$. Reaski yang terjadi tersebut menyebabkan $\mathrm{Cd}$ kehilangan sifat ionnya dan toksisitasnya dan menyebabkan kadar Cd menjadi turun setelah perendaman.

\section{Jenis Buah yang Memberikan Pengaruh Penurunan Paling Baik}

Berdasarkan penelitian yang telah dilakukan dapat diketahui bahwa semua jenis buah yang digunakan dapat memberikan pengaruh penurunan. Untuk mengetahui jenis buah manakah yang dapat memberikan pengaruh penurunan paling baik maka data yang sudah diuji melalui uji hipotesis diuji kembali dengan menggunakan uji BNJ (beda nyata jujur). Hasil uji yang telah didapatkan disajikan dalam bentuk grafik, hal ini dilakukan untuk mengetahui perbedaan 
penurunan kadar $\mathrm{Cd}$ pada masingyang dimaksud adalah yang tersaji masing perlakuan. Adapun grafik pada Gambar 3.

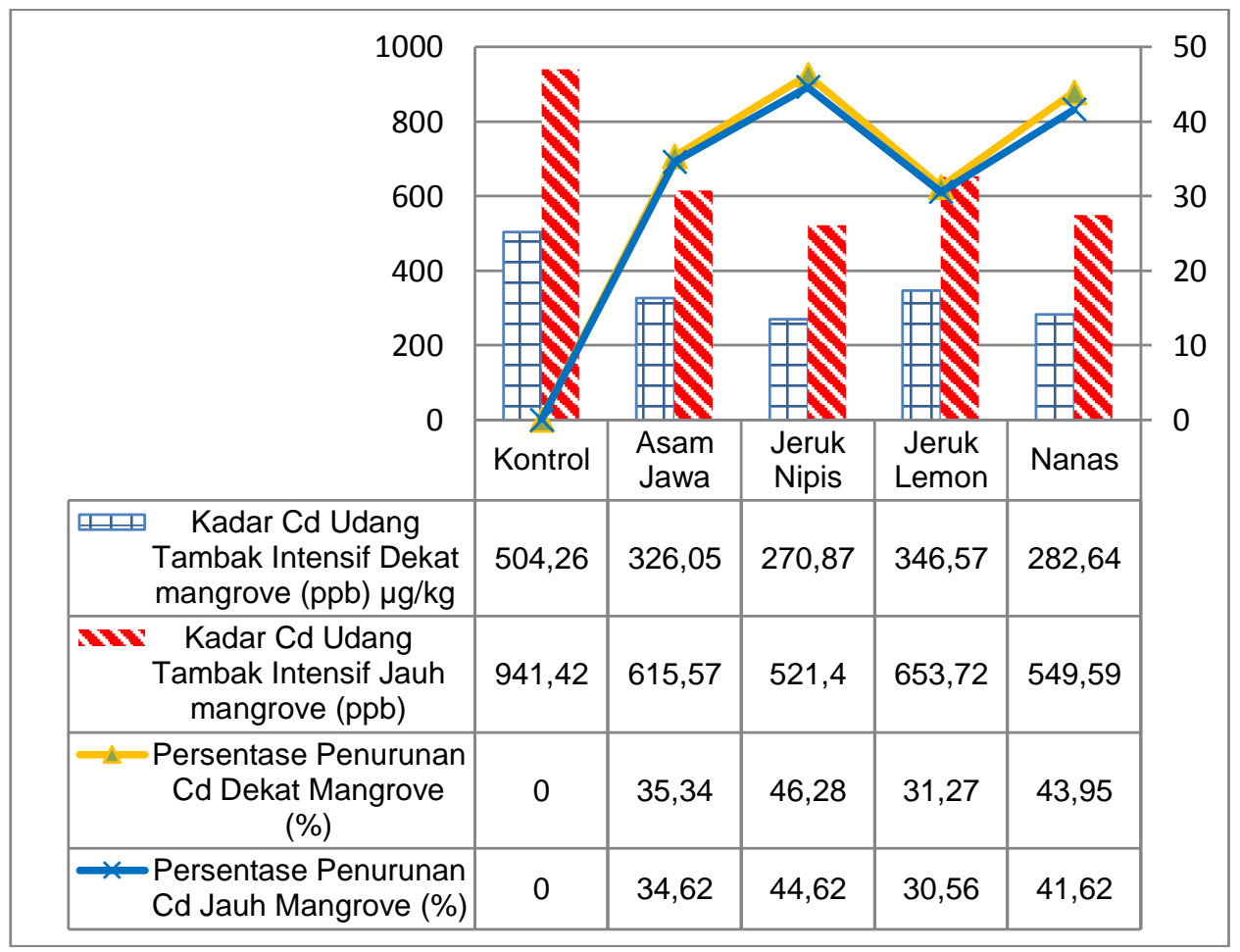

Gambar 3. Grafik rata-rata kadar Cd

Berdasarkan Gambar 3 di atas dapat diketahui bahwa pada udang tambak intensif dekat dan jauh mengrove jeruk nipis menurunkan kadar Cd paling baik pertama yaitu turun sebesar $46,28 \%$ untuk udang tambak intensif dekat mangrove dan $44,62 \%$, jauh mangrove. nanas kedua dengan penurunan masing-masing sebesar $43,95 \%$ dan $41,62 \%$, asam jawa ketiga dengan penurunan sebesar $35,34 \%$ dan $34,62 \%$. Jeruk lemon menghasilkan penurunan terkecil yaitu pada udang tambak intensif dekat mangrove turun sebesar $31,27 \%$ dan $30,56 \%$ untuk udang intensif jauh mangrove.

Banyaknya kandungan asam organik yang dimiliki suatu jenis buah berpengaruh pada banyaknya kadar logam yang terikat. Saputri dkk (2015: 136) menyatakan bahwa "asam sitrat banyak ditemukan pada buah golongan jeruk, yaitu limau, nipis dan jeruk purut". Selain pernyataan yang dikemukakan oleh Saputri dkk hasil uji analisis kandungan asam sitrat yang dilakukan di Laboratorium Universitas Muhammadiyah Malang juga menunjukkan bahwa jeruk nipis mengandung asam sitrat paling tinggi dibandingkan nanas, jeruk lemon, dan asam jawa. Hasil uji analisis asam sitrat pada jenis buah yang digunakanterpapar pada Tabel 3 berikut. 
Tabel 3. Total Kadar Asam Sitrat pada Jenis Buah

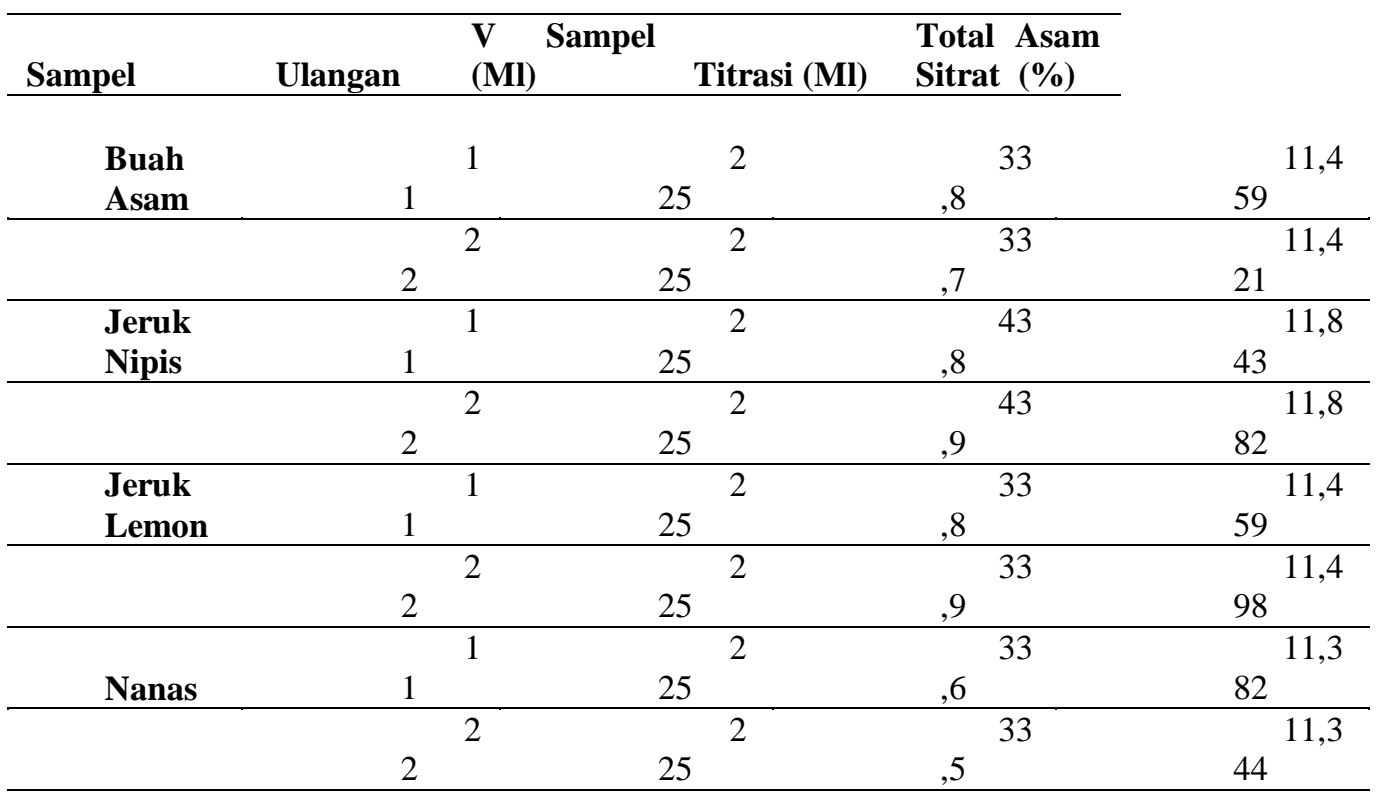

Priyadi dkk 2014: 441 menyatakan bahwa "keaktifan gugus fungsional karboksil - $\mathrm{COOH}$ dari asam sitrat dengan melepaskan ion $\mathrm{H}+$ menjadi ion sitrat $-\mathrm{COO}^{-}$ ditentukan oleh faktor $\mathrm{pH}$ khelasi" Sehingga ketika $\mathrm{pH}$ mengalami perubahan menjadi yang lebih asam akibat pemberian asam sitrat dengan kandungan tinggi maka akan mengakibatkan gugus fungsional karboksil akan menjadi lebih aktif dan $\mathrm{Cd}$ terikat lebih banyak. Oleh sebab itu jeruk nipis merupakan jenis buah yang memberikan pengaruh penurunan kadar Cd paling baik.

Penelitian ini menghasilkan sumber belajar berupa poster yang mendukung KD 3. 11 materi Pencemaran Lingungan. Berdasakan hasil validasi menunjukan bahwa dari segi desain dan materi poster layak digunakan sebagai sumber belajar peserta didik kelas X SMA materi Pencemaran Lingkungan dengan persentase sebesar $100 \%$ serta tidak terdapat revisi untuk desain dan persentase sebesar $96 \%$ untuk materi.
Hasil validasi yang didapatkan berada diatas nilai interval $81 \%$ $\leq$ skor $\leq 100 \%$ dan termasuk kedalam kategori sangat baik (Munawaroh, 2015) dan layak peserta didik kelas $X$ SMA materi Pencemaran Lingkungan.

\section{KESIMPULAN}

Berdasarkan penelitian yang telah dilakukan dapat disimpulkan bahwa perendaman daging udang vanname (Litopenaeus vannamei) dengan menggunakan jenis buah memberikan pengaruh penurunan kadar kadmium (Cd), jenis buah yang memberikan pengaruh penurunan paling baik adalah jeruk nipis yang mampu menurunkan kadmium $(\mathrm{Cd})$ sebesar $46,28 \%$ pada udang tambak intensif dekat mangrove, dan $44,62 \%$ pada udang intensif jauh mengrove. Penelitian ini menghasilkan sumber belajar berupa poster yang layak digunakan dalam pembelajaran biologi SMA kelas $\mathrm{X}$ dengan materi Pencemaran Lingkungan. 


\section{SARAN}

Berdasarkan penelitian yang telah dilakukan peneliti menyarankan untuk melakukan perendaman prodak perikanan seperti udang dengan menggunakan buah yang mengandung asam sitrat sebelum dikonsumsi agar dapat meminimalisir kandungan logam berat yang terakumulasi di dalamnya, dan memperhatikan ambang batas konsumsi logam berat dalam setiap produk makanan untuk menjaga kesehatan tubuh, mengingat logam berat seperti kadmium (Cd) dapat memberikan dampak buruk bagi kesehatan.

\section{DAFTAR PUSTAKA}

Badan Pengawas Obat dan Makanan Republik Indonesia Nomor 5 Tahun 2018 Batas

Cemaran Logam Berat dalam Makananan. 11 Mei 2018. Berita Negara Republik Indonesia Tahun 2018 Nomor 673. Jakarta.

Ilyasa, A. T., Susatyo, E. B., dan Prasetya, A. T. 2016. Penurunan Kadar Ion $\mathrm{Pb}$ dan $\mathrm{Cd}$ pada Kerang dengan Menggunakan Fitrat Kulit Nanas. Jurnal of Chemical Science, 5(3), h. 211-216.

Indirawati, S. M. 2017. Pencemaran Logam Berat $\mathrm{Pb}$ dan $\mathrm{Cd}$ dan Keluhan Masyarakat di Kawasan Pesisir Belawan. Jurnal Jumantik, 2(2), h. 5460.

Irawan, H., dan Yandri, F. 2015. Studi Biologi dan Ekologi Hewan Filum Crustacea di Zona Litoral Pesisir Timur
Pulau Bintan. Jurnal Studi Biologi dan Ekologi, 5(2), H. 37-48.

Izza, A. T., Hidayat, N., dan Mulyadi, A. F. 2014. Penurunan Kadar Timbal ( $\mathrm{Pb}$ ) pada Kupang Merah (Musculista senhausia)dengan Perebusan Asam pada Kajian Jenis dan Konsentrasi Asam. Jurnal of Chemical Science, 5(3), h. 110.

Khairuddin, Yamin, M., dan Syukur, A. 2018. Analisis Kandungan Logam Berat pada Tumbuhan Mangrove sebagai Bioindikator di Teluk Bima.Jurnal Biologi Tropis, 18(1), h. 75-85.

Kusumaningrum, $\quad$ H. $\quad$ P., Herusugondo., Zainuri, M., dan Raharjo, B. 2012. Analisis Kandungan Kadmium (Cd) dalam Tanaman Bawang Merah dari Tegal. Jurnal Sains dan Matematika, 20(4), h. 98102.

Maulana, F., Muhammad, S., Nurmaida, A. L., dan Sukma, W. A.2018. Pengaktifan Kulit Asam Jawa dengan Campuran Asam Sitrat dan Asam Tartarat untuk Penyerapak Ion Logam $\mathrm{Cd}$ (II). Jurnal Rekayasa Kimia dan Lingkungan,13(2), h. 135-143.

Megawati. 2017. Pengaruh Media

Poster Terhadap Hasil

Belajar Kosakata Bahasa Inggris. Getsemena English Eduction Journal, 4(2), h. 101-117.

Munawaroh, F., dan Wulandari, A. Y. R. 2015. Pengembangan 
Modul Praktikum Jembatan Wheatstone Menggunakan Macromedia Flash 8. Jurnal Ilmiah Rekayasa. 8(2),h. 8794.

Nur, F. 2013. Fitoremediasi Logam Berat Kadmium (Cd). Jurnal Biogenesis, 1(1), h. 74-83.

Nurmalasari. dan Zaenab. 2015. Pemanfaatan Air Perasan Jeruk Nipis (Citrus aurantifolia swingle) dalam Menurunkan Kadar Logam Berat $\mathrm{Pb}$ Yang Terkandung pada Daging Kerang. Jurnal Higiane, 1(3), h. 168-174.

Ondu, A. F., Jayadipraja, E. A., dan Sunarsih. 2019. Efektifitas Citrus aurantifoliaswingle dan Averroa bilimbi dalam Menurunkan Konsentrasi Timbal pada Kerang Kalandue (Polymesoda sp) dari Teluk Kendari. Jurnal Higiene, 5(1), h. 1-13.

Priyadi, S., Darmadji, P., Santoso, U., dan Hastuti, P. 2014. Distribusi Plumbum, Kadmium pada Biji Kedelai, dan Deprotonisasi GugusFungsional Karboksil Asam Sitrat dalam Khelasi.Jurnal Agritech, 34(4), h. 407-413.

Rohmana, Q. A., Wahyono, P., dan Hadi, S. 2015. Pengaruh Sari Buah Nanas (Ananas comosus) dan Lama Penyimpanan terhadap Jumlah Koloni Bakteri dan Kadar Protein Ikan Bandeng (Chanos chanos) sebagai Sumber Belajar dalam Perencanaan Pembelajaran Biologi Materi Kingdom
Monera. Jurnal Pendidikan Biologi Indonesia, 1(1), h. 60-70.

Saadah, W. dan Milah, K. 2019. Permintaan Udang Vannamei (Litopenaeus vannamei) di Kelompok Pembudidaya Udang At-Taqwa Paciran Lamongan. Jurnal Perikanan Masyarakat Ilmiah Berwawasan Agribisnis, 5(2), h. 243-251.

Sandesta. 2019. Pengaruh Ekstrak Belimbing Wuluh (Averrhoa bilimbi) dalam Menurunkan Timbal (Pb) pada Siput Gonggong (Strombus turturella) dari Pantai Permai Bangka Selatan. Tesis tidak diterbitkan. Palembang: Pertanian Universitas Sriwijawa Palembang.

Saputri, M. R., Rachmadiarti, F., dan Raharjo. 2015. Penurunan Logam Berat Ikan Nila (Oreochromis nilotica) Kali Surabaya Menggunakan Fitrat Jeruk Siam (Citrus nolibis).Jurnal Lentera Bio, 4(2), h.136-142.

Sipa, Y. N., Jamaludin., dan Ihwan. 2016. Pengaruh Jenis Asam Alami Terhadap Penurunan Kadar Logam Berat Timbal dalam Daging Ikan Teri (Stelophorus indicus sp) Asal Teluk Palu. Jurnal Kovalen, 2(3), h. 80-85.

Surest, A. H., Ovelando, R., dan Nabila, M. A. 2013. Fermentasi Buah Markisa (Passiflora) Menjadi Asam Sitrat. Jurnal Teknik Kimia, 3(19), H. 15-28. 
Yusbarina, dan Marlianis. 2013.

Penurunan Kadar Limbah

Logam Timbal $(\mathrm{Pb})$ dengan

Metode Khelasi

Menggunakan Belimbing

Wuluh (Averrhoabilimbi).

Jurnal Photon, 4(1), h. 1-8. 
